\title{
Conf-910920--17
}

WSRC-MS- $-91-025$

DE9 2009628

\section{AQUEOUS EFFLUENT TRITIUM MONITOR DEVELOPMENT (U)}

by

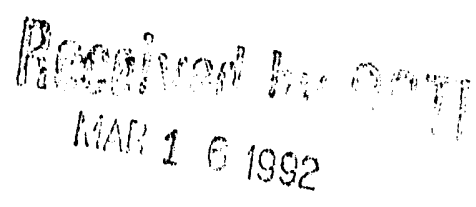

K. J. Hoffstetter, et al.

Westinghouse Savannah River Company

Savannah River Site

Aiken, South Carolina 29808

A paper proposed for publication at the

Fourth ANS Topical Meeting on Tritium Technology in Fission, Fusion and

Isotopic Applications

Albuquirque, New Mexico

September 30-October 4, 1991

\author{
DISCLAIMER
}

\begin{abstract}
This report was prepared as an account of work sponsored by an agency of the United States Government. Neither the United States Government nor any agency thereof, nor any of their employees, makes any warranty, express or implied, or assumes any legal liability or responsibility for the accuracy, completeness, or usefulness of any information, apparatus, product, or process disclosed, or represents that its use would not infringe privately owned rights. Reference herein to any specific commercial product, process, or service by trade name, trademark, manufacturer, or otherwise does not necessarily constitute or imply its endorsement, recommendation, or favoring by the United States Government or any agency thereof. The views and opinions of authors expressed herein do not recessarily state or reflect those of the United States Government or any agency thereof.
\end{abstract}

This paper was prepared in connection with work done under Contract No. DE-AC09-89SR18035 with the U.S. Department of Energy. By acceptance of this paper, the publisher and/or recipient acknowledges the U.S. Government's right to retain a nonexclusive, royalty-free license in and to any copyright covering this paper, along with the right to reproduce and to authorize others to reproduce all or part of the copyrighted paper.

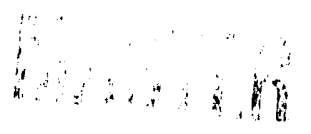

DISTIBUTION OF THIS DOCUMENT IS UHLIMAY: 


\title{
AQUEOUS EFFLUENT TRITIUM MONITOR DEVELOPMENT
}

\author{
K. J. Hofstetter and H. T. Wilson \\ Westinghouse Savannah River Company \\ Savannah River Laboratory \\ Aiken, SC 29808
}

\begin{abstract}
The development of a low-level tritium monitor for aqueous effluents has explored several potential techniques. In one method, a water-immiscible liquid scintillation cocktail was ultrasonically mixed with an aqueous sample to form a water-cocktail dispersion which was analyzed by liquid scintillation spectrometry. The organic cocktail could then be reused after phase separation. Of the cocktails tested, the highest tritium detection efficiency $(7 \%)$ was determined for a toluene-based cocktall. In another technique, the response of various solid scintillators (plastic beads, crushed inorganic salts, etc.) to tritium solutions was measured. A 2\% tritium detection efficiency was cosserved for the most efficient solid scintillators tested. In a third method, a large surface area detector was constructed from thin fibers of plastic scintillator. This detector had a $0.1 \%$ intrinsic tritium detection efficiency. While sensitivities of $25 \mathrm{kBq} / \mathrm{L}$ of tritium for a short count have been attained using several of these techniques, none can reach the environmental level of $<1 \mathrm{kBq} / \mathrm{L}$ in aqueous solutions.
\end{abstract}

\section{INTRODUCTION}

There is presently no commercially available on-line monitor for tritium in aqueous solutions. The sources of tritiated water in the environment and the difficulties in developing a tritium monitor with real-time response have been reported (e.g., Reference 1 ).

A monitor capable of continuously measuring tritium in aqueous solutions could improve many operations that involve tritium as a product or as an impurity (e.g., heavy water purification, heavy water moderated reactors, etc.). Process control at such facilities is typically performed by batch sampling and laboratory analysis. The strategic location of tritium monitors throughout the process could improve the efficiency of the operation and alert personnel to process upsets. Installed on the effluent, a monitor could mitigate an unplanned tritium release and its consequences by stopping the effluent flow when high tritium concentrations were detected. The sensitivity requirements for each monitor would depend on the type of process and its location within the process. For example, an analysis of the discharge pathway from the heavy water purification facility at SRS indicates that an effluent monitor should be capable of detecting a 
tritium concentration of $37 \mathrm{kBq} / \mathrm{L}$ within several minutes. A real-time monitor for tritium in environmental streams could also be used to verify compliance with existing regulations. Compliance monitoring is now performed exclusively by proportional sampling and laboratory analyses. This practice has been acceptable due to the historically low tritium levels in the environment and to the low biological hazard associated with tritiated water. However, from a public perception point of view, it is desirable to have onIine monitoring for tritium in aqueous streams to verify that EPA Drinking Water standards $(0.74 \mathrm{kBq} / \mathrm{L})$ (2) are not being exceeded, for example. The advantages of continuously monitoring radionuclide releases from commercial ( 3 ) or DOE facilities (4) in real time are obvious. The sensitivity levels for compliance monitoring are much lower than required for process control or breakthrough monitoring and should be well below the applicable standard.

The monitors should be field hardened to environmental or process conditions, operate unattended for long periods of time, be simple to calibrate and operate, be easy to maintain, and provide stable readings under steady state conditions. A semi-continuous tritium monitoring technique has been reported using water soluble cocktails in a suitable flow cell ( $\underline{5}$ ) but the cost of the cocktails for continuous operation would be high and their discharge to the environment questionabie. Recycling the cocktail is under investigation (6). The concepts under evaluation in this study include the use of water immiscible liquid scintillation cocktails, plastic beads of solid scintillators or crushed inorganic scintillators, and thin fibers made from plastic scintillator material as possible real-time tritium detectors. The background, efficiency, sensitivity, precision, and accuracy of each detector system are presented along with the advantages and disadvantages of each technique.

\section{WATER-IMMISCIBLE LIQUID SCINTILIATION COCKTAILS}

Experiments were performed to evaluate water insoluble liquid scintillation cocktails as a means of detecting tritium in aqueous solutions. Conceptually, an aqueous sample is mixed with the water-immiscible cocktail and the semi-stable dispersion analyzed by standard liquid scintillation counting techniques. After counting, the suspension was separated, the aqueous phase was discarded, and the cocktail was subsequently reused. Various cocktail-water combinations were tested after ultrasonic mixing and the efficiency, suspension time, separation time, and recycle capability of each were determined.

Samples of four major types of liquid scintillation cocktails (toluene, xylene, mineral oil, and pseudocumene) were obtained from commercial vendors for testing. A small ultrasonic mixer with a frequency of $25 \mathrm{kHz}$ and a power output of 20 watts, was 
filled with water and used throughout these experiments. A Packard Model 2000IB liquid scintillation counter was used for counting the dispersions. Tritium beta spectra were recorded to evaluate changes in spectral shape as the dispersion began to separate into two phases. special counting protocols were developed to acquire and store the spectra on computer compatible disks.

Various combinations of mixing times and ratios of aqueous to organic phase were tested in a systematic manner for each cocktail. These procedures were then repeated using the recycled cocktail, both before and after backwashing with deionized water. The optimum tritium detection efficiency occurred when $1 \mathrm{~mL}$ of a tritium spiked aqueous sample was mixed with $15 \mathrm{~mL}$ of cocktail.

The results of the tests showed that the toluene- and xylenebased cocktails had the highest tritium detection efficiency. The observed tritium counting efficiencies are given in Table I. In addition to low detection efficiency, the mineral oil and pseudocumene-based cocktails did not mix well, agglomerating and sticking to the walls of the vial. While the xylene-based cocktail had the highest counting efficiency, the toluene-based cocktail showed the better tendency to mix and yet quickly separate from the aqueous phase. The detailed procedure and results of the study have been presented ( 7 ). In summary, the average tritium counting efficiency for the tests with the xylene-based cocktail was $7.1 \pm 2.3$ percent ( $32 \%$ 20 relative standard deviation (RSD)). similar tests using the toluene-based cocktail yeilded an average tritium counting efficiency of $2.8 \pm 3.1$ percent ( $39 \% 20$ RSD).

It was observed that after washing fresh cocktail or backwashing used cocktail, a white precipitate formed which did not tend to settle during phase separation. one or mare of the components of the liquid scintillation cocktail mixture may be extracting as a result of repeated aqueous washing. This speculation may also explain some of the inconsistent. results for counting efficiency. Changes in the volume ratios and mixing times did not improve the detection efficiency or the measurement precision. The external standard method of quench correction showed no correlation with the observed counting results. Additional experiments with different scintiliators or different mixing methods are suggested.

\section{SOLID SCINTILLATORS}

Various solid scintillators have been tested for tritium response using a commercial instrument originally designed to detect labeled compounds separated by a high pressure liquid chromatograph (HPLC). The system was described in reference 1 along with the results of the experiments with the yttrium silicate inorganic scintillator provided with the system. The other solid scintillators tested to date are beads of 
plastic scintillator in three size fractions (see Table II). The beads are manufactured by Bicron, Inc. from product BC400. To test the beads, special FEP Teflon tubing was formed into a U-tube, the beads poured into the tube, and $f$ !red in the bottom with glass wool plugs. The U-tube containing the beads was placed in a cell holder, connected to a liquid recirculation system, and placed in the instrument. The Utube configuration was similar to that supplied by the vendor for the yttrium silicate cell with a $1 \mathrm{~mL}$ void volume. Two different sizes of FEP tubing were used for the bead tests $(6.4 \mathrm{~mm}$ and $4.8 \mathrm{~mm}$ ID).

A solution recirculation system was assembled which included a HPLC pump capable of producing a controlled flow (1-2 $\mathrm{mL} / \mathrm{min})$ at high pressures. The aqueous solution was pumped from a storage reservoir, through the measurement cell, and back to the storage reservoir. Flow and pressure measurements were made during the system operation. Because Teflon tubing was used in the measurement cells, all tests were performed with an upper operating limit of $700 \mathrm{kPa}$ differential pressure.

The electronic parameters, e.g., high voltages, lower and upper level discriminators, amplifier gains, coincidence resolving time, etc. were set per the manufacturer's recommendations for the yttrium silicate cells. These parameters remained constant throughout the testing program for all scintillators. Data were acquired by a computer based data acquisition system. The average count rates in the tritium and gross beta counting channels were output every hour while the real-time display of the data was updated every 10 minutes.

A typical test of each scintillator ran for 7-10 days. During the first few days, deionized water was circulated through the cell and data collected on the background count rate. For the next several days, the intake of the HPLC pump vas switched to a tritium spiked aqueous solution with specific activity of 250-300 kBg/L. This solution was recirculated through the cell, sampled, and analyzed by standard liquid scintillation counting. The response of the system to the tritium solution was compared to the analysis result. The system was then flushed with deionized water for several days. A plot of the data recorded during a typical run is shown in Figure 1 . Note that the data recorded in the gross-beta channel is independent of the tritium concentration.

Table II gives a comparison of the figure of merit (FOM) of the various solid scintillator/cell configurations as expressed as $E^{2} / B$ where $E$ is the detection efficiency (cpm/concentration) in percent and $B$ is the background in cpm. of the systems tested, the $0.4 \mathrm{~mL}$ cell filled with crushed Yt silicate had the highest FOM. This cell has a spiral geometry. The FOM for the $4.8 \mathrm{~mm}$-tube containing plastic scintillator beads in the size range $0.1-0.25 \mathrm{~mm}$ was cinly $10 \%$ 
lower than the $0.4 \mathrm{~mL}$ cell. While the yttrium silicate cells had higher detection efficiencies, they also had a higher backgrounds leading to comparable FoMs. In addition, the cells containing crushed scintillator had high differential pressure (400-600 kPa) which plugged more quickly when exposed to solutions containing particulates. The back pressure on the cells containing $0.1-0.25 \mathrm{~mm}$ beads was <70 $\mathrm{kPa}$.

The sensitivity of each measurement cell was calculated as the minimum detectible activity $(\underline{8})$. Using this formalism, the tritium counting efficiency, background, sample size, and count time were combined to evaluate each cell's ability to detect events which are statistically above background. The results are summarized in Table III for several arbitrary counting times. The counting times chosen indicate each cell's ability to detect a change in concentration over a short interval, an intermediate interval, and over an extended period. The results show that a release producing tritium concentrations $>25 \mathrm{kBq} / \mathrm{L}$ could be detected within ten minutes by cells containing small scintillator beads and cells containing Yt silicate. While this may be adequate for process control or breakthrough monitoring, none of the scintillator/cell configurations can reach the $<1 \mathrm{kBq} / \mathrm{L}$ sensitivity goal for compliance monitoring even when the data are pooled over a period of one day. Additional experiments with smaller beads in smaller diameter cells are suggested.

\section{PLASTIC SCINTILLATION FIBERS}

A monitor capable of continuously measuring low tritium concentrations requires a detector with high tritium detection efficiency. A detector cell was constructed with $477-1.0 \mathrm{~mm}$ diameter $X 50 \mathrm{~mm}$ long plastic scintillator fibers yielding an effective surface area of $750 \mathrm{~cm}^{2}$. Since the maximum range of the tritium beta particle in water is about 6 microns, the effective interaction volume is only $0.5 \mathrm{~mL}$ even though the liquid volume of the cell is about $100 \mathrm{~mL}$. The fibers, manufactured by Bicron, Inc., were equally spaced on $2 \mathrm{~mm}$ centers, and glued individually into two pre-drilled Lexan plates which served as the ends of the cell. All other cell components were made from Lexan and were coated with reflective paint on their interior surfaces. The flow of liquid is perpendicular to the fibers. The outside ends of the fibers protruding through the Lexan plates were polished and then optically coupled to a pair of Philips XP2202B photomultiplier tubes (PMT).

standard fast-slow coincidence electronics were used in the post-detector amplification and timing systems. The PMT anode outputs were used in the timing circuit as the coincidence requirement $(2 \tau=5.8 \mathrm{nsec})$ while the dynode outputs were summed for energy analysis. High gain demanded operating the PMTs at or near their maximum voltages ( +2000 Volts). 
Energy calibration was accomplished using gamma-ray point sources positioned outside the measurement cell. The resulting compton spectra were analyzed by standard pulse height analysis techniques. Figure 2 displays three spectra taken with one of the PMTs and the results of the analysis of the highest energy component in each compton spectrum. The gain of each PMT was matched by high voltage adjustment before the signals were summed for energy analysis. Beta spectra were then taken with and without tritium solutions circulating through the cell and the final single channel analyzer (SCA) window adjustments were made. The SCA signal was then fed to a linear gate which passed the energy pulse provided the coincidence requirement was met.

Figure 3 displays the monitor output when deionized water and tritium spiked water were circulated through the system. A recirculation system similar to that used during the testing of the other solid inorganic scintillators was used for these tests. The major difference was that this system circulated solutions at a nominal flow of $30 \mathrm{~mL} / \mathrm{min}$. The data shown in Figure 3 results in a bulk efficiency (cpm/concentration) of $0.1 \%$ for this detection cell. Because of the high background, the FOM for this system is significantly lower than that calculated for the other solid scintillators tested. A lower sensitivity limit of $100 \mathrm{kBg} / \mathrm{L}$ has been calculated from these data. The design of an improved cell is nearing completion. New high gain, low noise PMTs and preamplifiers will be tested to improve the system performance.

\section{CONCLUSIONS}

While additional experiments are underway to investigate the use of immiscible liquid scintillation cocktails as an on-line aqueous tritium effluent monitor, the most promising technique employs stationary solid scintillators as tritium detectors. These type detectors have application as piocess control and breakthrough monitors with the current techrology. To explore solid scintillators as compliance monitors, calculations of the maximum tritium detection efficiency have been performed. Monte-Carlo methods were used to generate the maximum efficiency for an aqueous solution in contact with a detecting surface. The extremes of the calculations were established by the maximum beta range for tritium in water. This limit

established an effective interaction volume for the sensor per unit area. Applying the Monte Carlo method outlined by Rucker et. al (9), an efficiency of $9.4 \pm 0.3 \%$ per unit area was calculated assuming $100 \%$ intrinsic detection efficiency (i.e., all events reaching the scintillator are detected). This efficiency was compared to that observed for all solid scintillators tested. The result of this comparison is shown in Table IV. In the case of the inorganic scintillators, the cell void volume was assumed to be the interaction volume. In one experiment, four fibers (150 mm long) were placed in the $\mathrm{U}$-tube cell and the response recorded as tritium solution 
flowed through the cell. In this experiment, the scintillations were viewed perpendicular to the fiber length. It can be seen from the data in Table IV. that all the experimental efficiencies are less than the computed maximum. Part of this is due to the imprecise treatment of the low energy portion of the beta spectrum in the calculation while part is due to the low-energy threshold of scintillators.

The data suggest that a combination of large surface area scintillators with low specific volume, e.g., a large bundle of smaller diameter fibers, could produce a detector with sufficient tritium efficiency to operate as an environmental monitor. Other combinations of scintillators and cell configurations are being tested during the cievelopment of a tritium monitor for aqueous streams.

\section{REFERENCES}

(1) K. J. Hofstetter, "Development of Aqueous Tritium Effluent Monitor", Liquid Scintillation Counting and organic Scintillators, ed. Harley Ross, John E. Noakes, and Jim D. spaulding, (Chelsea, Michigan: Lewis Publishers, Inc., 1991), pp. $421-433$.

(2) Code of Federal Regulations, "National Primary Drinking Water Regulations", 4OCFR, Part 141, Washington DC, pp. 526575 (1987).

(3) Code of Federal Regulations, "Domestic Iicensing of Production and Utilization Facilities", 10CFR, Part 50, Appendix A. Washington DC, (1990).

(4) US Department of Energy, "General Environmental Protection Program", Order DOE 5400.1, Washington DC, (1988).

(5) R. J. Budnitz, "Tritium Instrumentation for Environmental and occupational Monitoring - A Review", Health Physics, 26, 165 (1974).

(6) R. A. Sigg, "A Continuous Aqueous Tritium Monitor Using Membrane Technology", Proceedings of this Conference.

(7) K. J. Hofstetter and H.T. Wilson, "Aqueous Tritium Detection Using Immiscible Liquid Scintillation Cocktails", 1991 ANS Winter Meeting, San Francisco, November 10-14, 1991.

(8) L. A, Currie, "Limits for Qualitative and Quantitative Detection", Analytical Chemistry, 40, 586 (1968).

(9) T. L. Rucker, H. H. Ross, and G. K. Schweitzer, "Monte Carlo Modeling of Fiber-Scintillator Flow-Cell Radiation Detector Geometry", Nuclear Instruments and Methods, A267, 511-519, (1988). 
Table I. Liquid Scintillation Cocktails used During the Testing with Measured Range of Tritium Detection Efficiencies

$\begin{array}{ccc}\text { Vendor/Trade Name Cocktail Base } \begin{array}{c}\text { Efficiency } \\ \text { Range }\end{array} & \begin{array}{c}\text { Eff. } \\ \text { Ave. }\end{array}\end{array}$

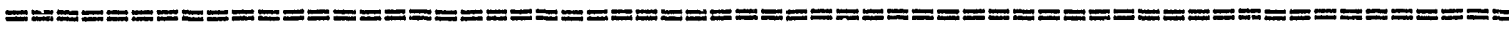

Packard/Insta-Flor

Xylene

$3-11 \%$

$7.1 \%$

Packard/Perma-Flor

Toluene

$1-5 \%$

$<2 \%$

$2.8 \%$

Pseudocumene

$<1 \%$

$1.2 \%$

$0.8 \%$

Mineral oil

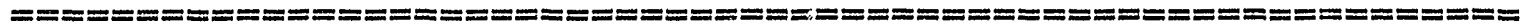


Table II. A summary of the solid scintillators tested in this study. The Figure of Merit is the square of the tritium detection efficiency in percent divided by the background count rate in cpm.

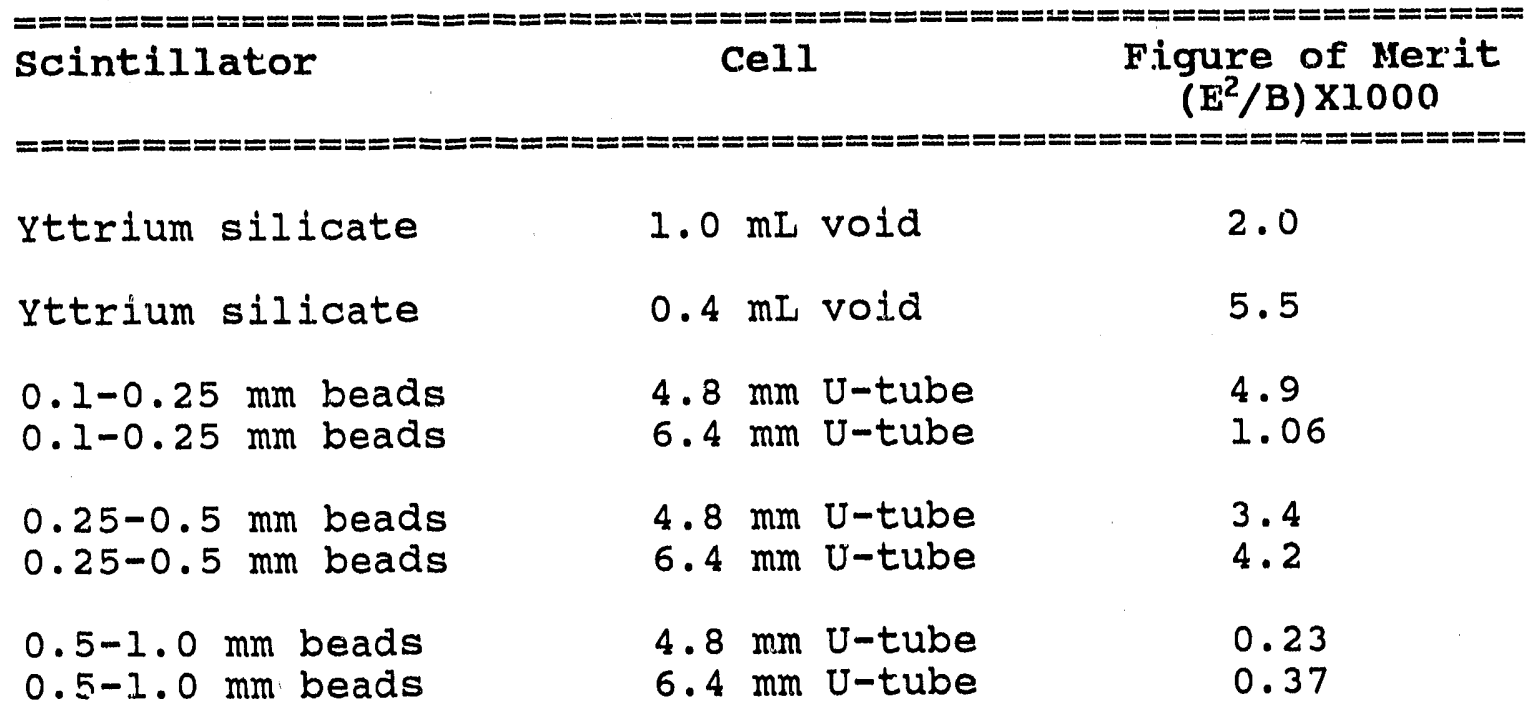


Table III. The minimum detectible tritium concentrations $(\mathrm{kBq} / \mathrm{L})$ calculated for several counting intervals for pach solid scintillator tested. See explanation in text.

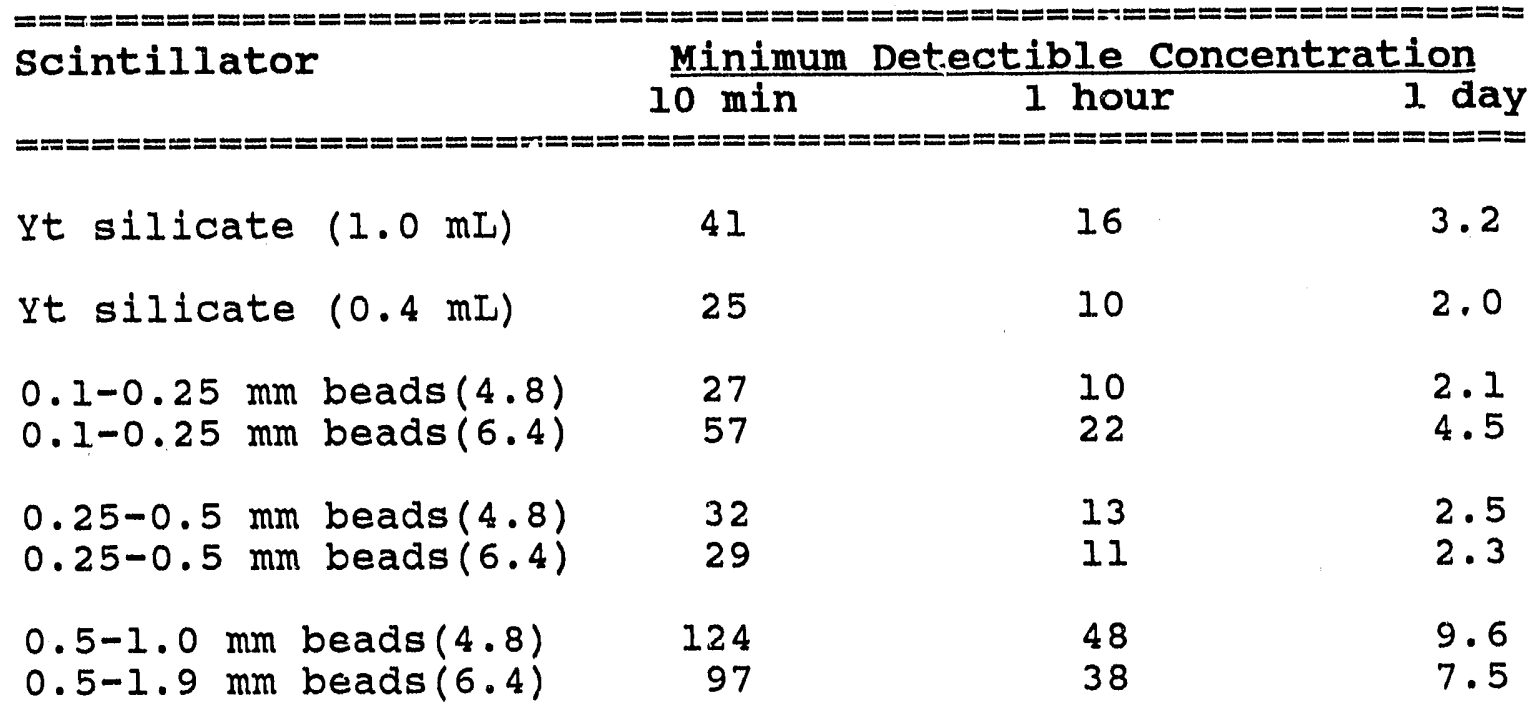


Table IV. Comparison of observed detector efficiencies for the solid scintillators reported in this study. The interaction volume is the surface area of the detector times the maximum range of the tritium beta particle $(6.6 \mu \mathrm{m})$.

\begin{tabular}{|c|c|c|c|}
\hline Scintillator & $\begin{array}{l}\text { Area } \\
\mathrm{Cm}^{2}\end{array}$ & $\begin{array}{l}\text { Int. Volume } \\
\mathrm{cm}^{3}\end{array}$ & $\begin{array}{l}\text { Efficiency } \\
\text { (q) }\end{array}$ \\
\hline Yt silicate $(1.0 \mathrm{~mL})$ & -- & 1.0 & 0.18 \\
\hline It silicate $(0.4 \mathrm{~mL})$ & -- & 0.4 & 0.73 \\
\hline $\begin{array}{l}0.1-0.25 \mathrm{~mm} \text { beads }(4.8) \\
0.1-0.25 \mathrm{~mm} \text { beads }(6.4)\end{array}$ & $\begin{array}{l}187 \\
327\end{array}$ & $\begin{array}{l}0.123 \\
0.215\end{array}$ & $\begin{array}{l}1.69 \\
0.51\end{array}$ \\
\hline $\begin{array}{l}0.25-0.5 \mathrm{~mm} \text { beads }(4.8) \\
0.25-0.5 \mathrm{~mm} \text { beads }(6.4)\end{array}$ & $\begin{array}{r}98 \\
172\end{array}$ & $\begin{array}{l}0.065 \\
0.113\end{array}$ & $\begin{array}{l}2.65 \\
1.82\end{array}$ \\
\hline $\begin{array}{l}0.5-1.0 \mathrm{~mm} \text { beads }(4.8) \\
0.5-1.9 \mathrm{~mm} \text { beads }(6.4)\end{array}$ & $\begin{array}{l}43 \\
76\end{array}$ & $\begin{array}{l}0.028 \\
0.050\end{array}$ & $\begin{array}{l}1.66 \\
1.16\end{array}$ \\
\hline $\begin{array}{l}4 \text { fibers ( } 1.0 \phi \times 150 \mathrm{~mm}) \\
477 \text { fibers ( } 1.0 \phi \times 50 \mathrm{~mm})\end{array}$ & $\begin{array}{l}4.8 \\
749\end{array}$ & $\begin{array}{l}0.003 \\
0.493\end{array}$ & $\begin{array}{l}4.64 \\
0.22 \\
\end{array}$ \\
\hline
\end{tabular}

LIST OF FIGURES

Figure 1. Hourly average count rate data obtained from a 4.8 $\mathrm{mm}$ Teflon U-tube filled with $0.1-0.25 \mathrm{~mm}$ plastic scintillator beads. Water spiked with tritium is introduced into the system and then subsequently flushed.

Figure 2. Compton spectra obtained from point sources located outside the cell. Analysis of the maximum energy component was used to establish energy calibration.

Figure 3. A plot of the count rate seen by the fiber detector when exposed to tritium spiked water in a recirculation

experiment followed by a deionized water flush. 
(Figures are DRAFT)

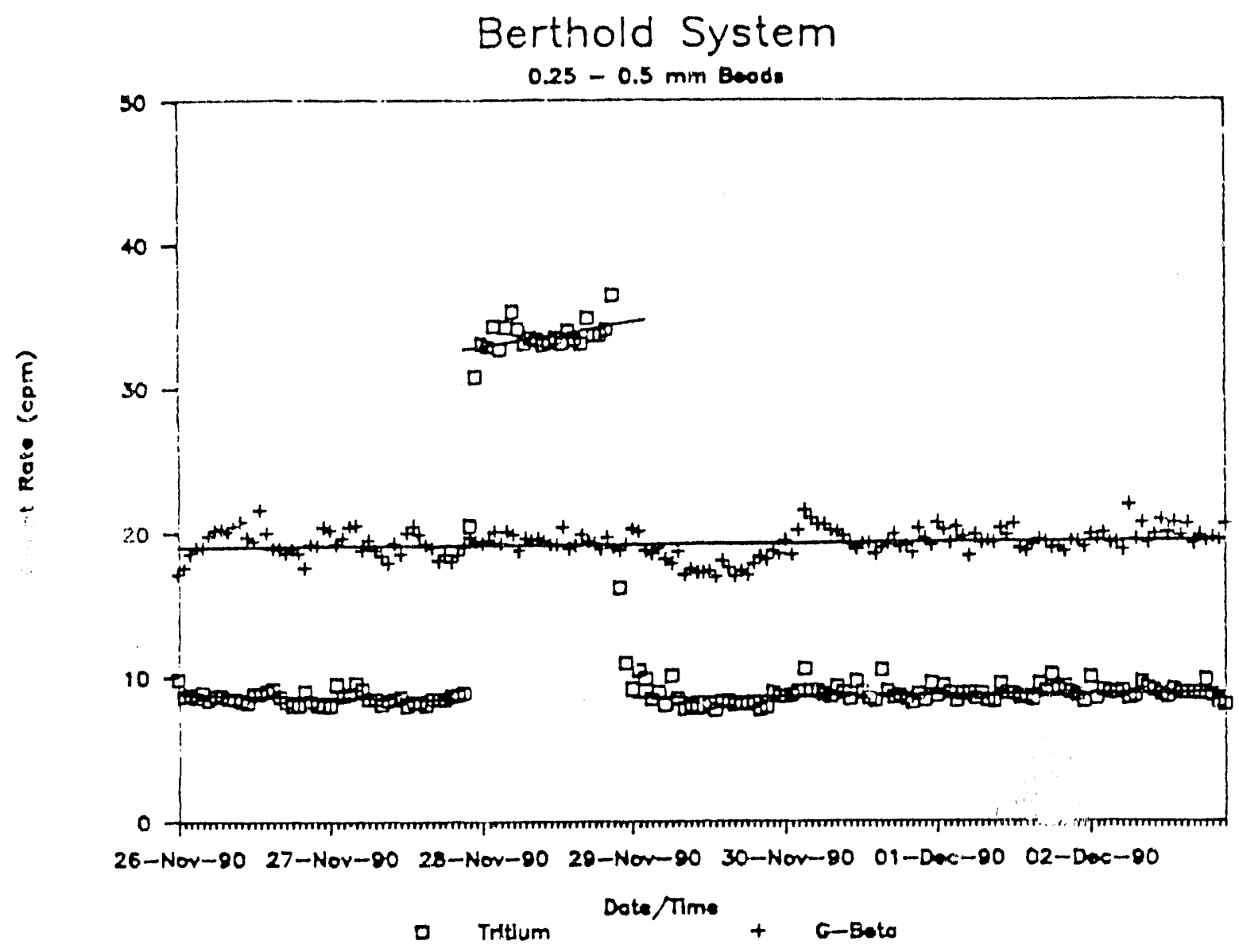

Figure 1. Hourly average court, rate data obtained from a 4.8 mim Teflon U-tube filled with $0.1-0.25 \mathrm{~mm}$ plastic scintiliator beads. Water spiked with tritium is introduced into the system and then subsequently flushed. 


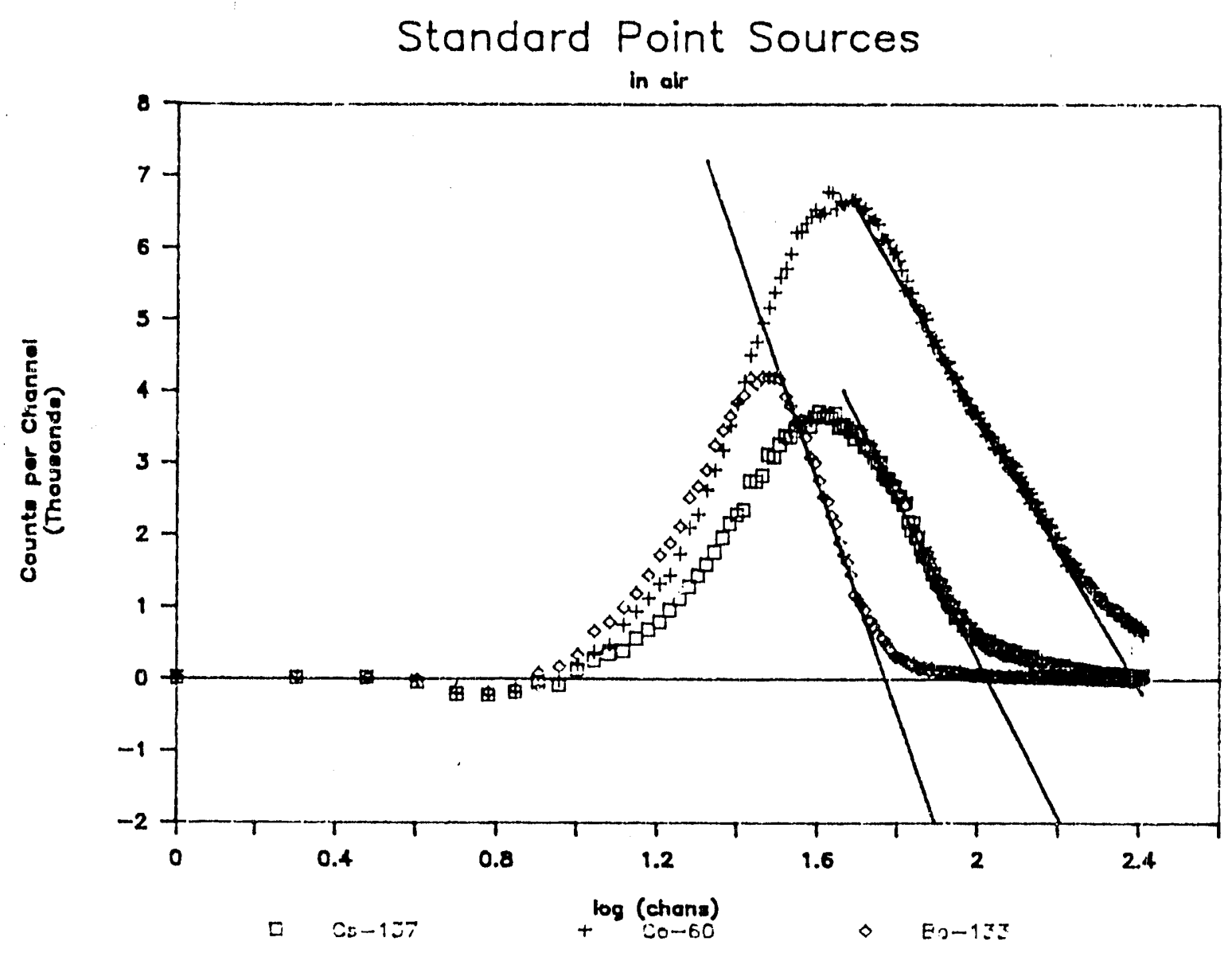


Fiber Detector

Fout coln + sca

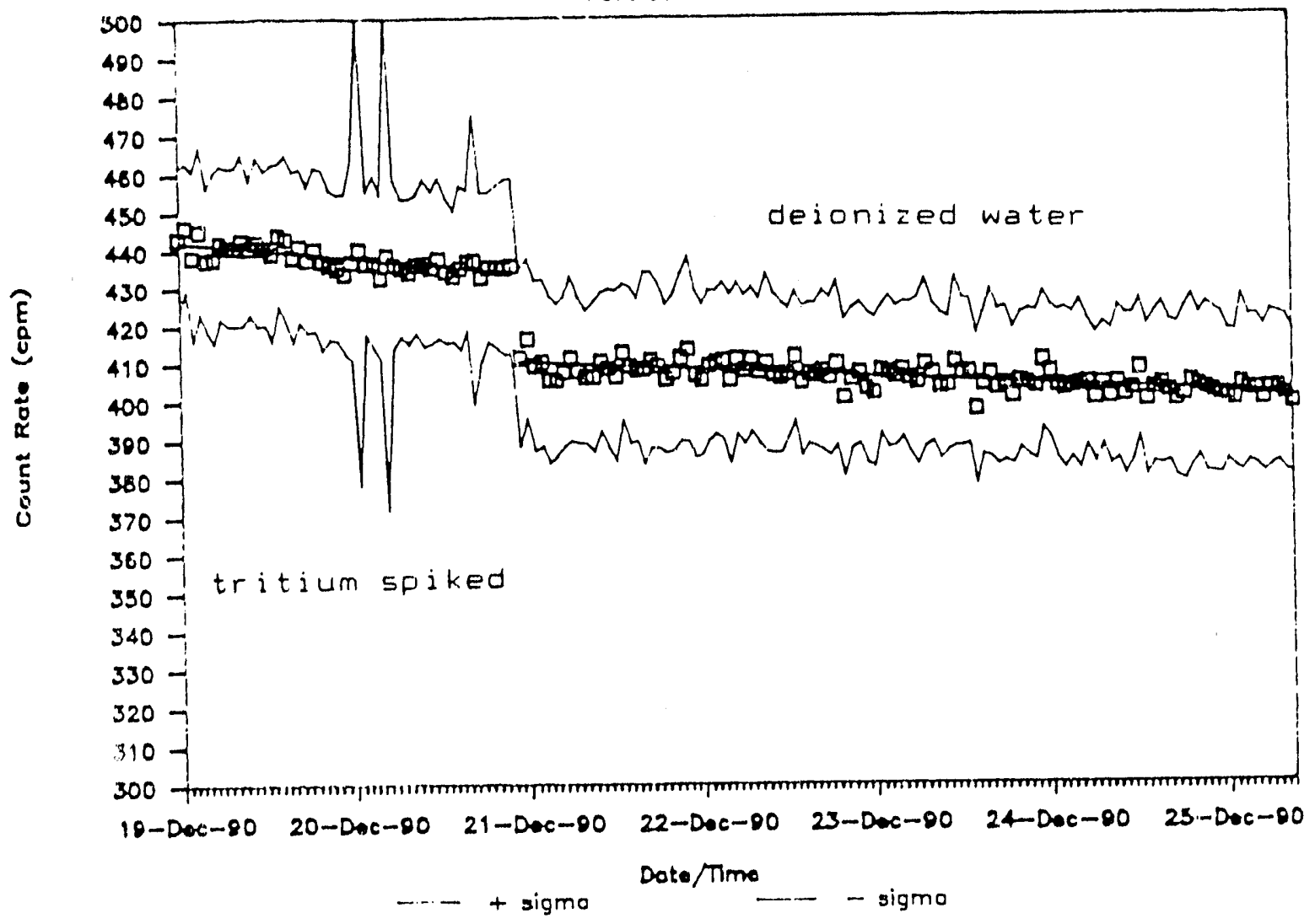

Figure "3. A plot of the count rate seen oy the fiber detector when exposed to tritium spiked water in a recirculation experiment followed by a deionized water flush. 

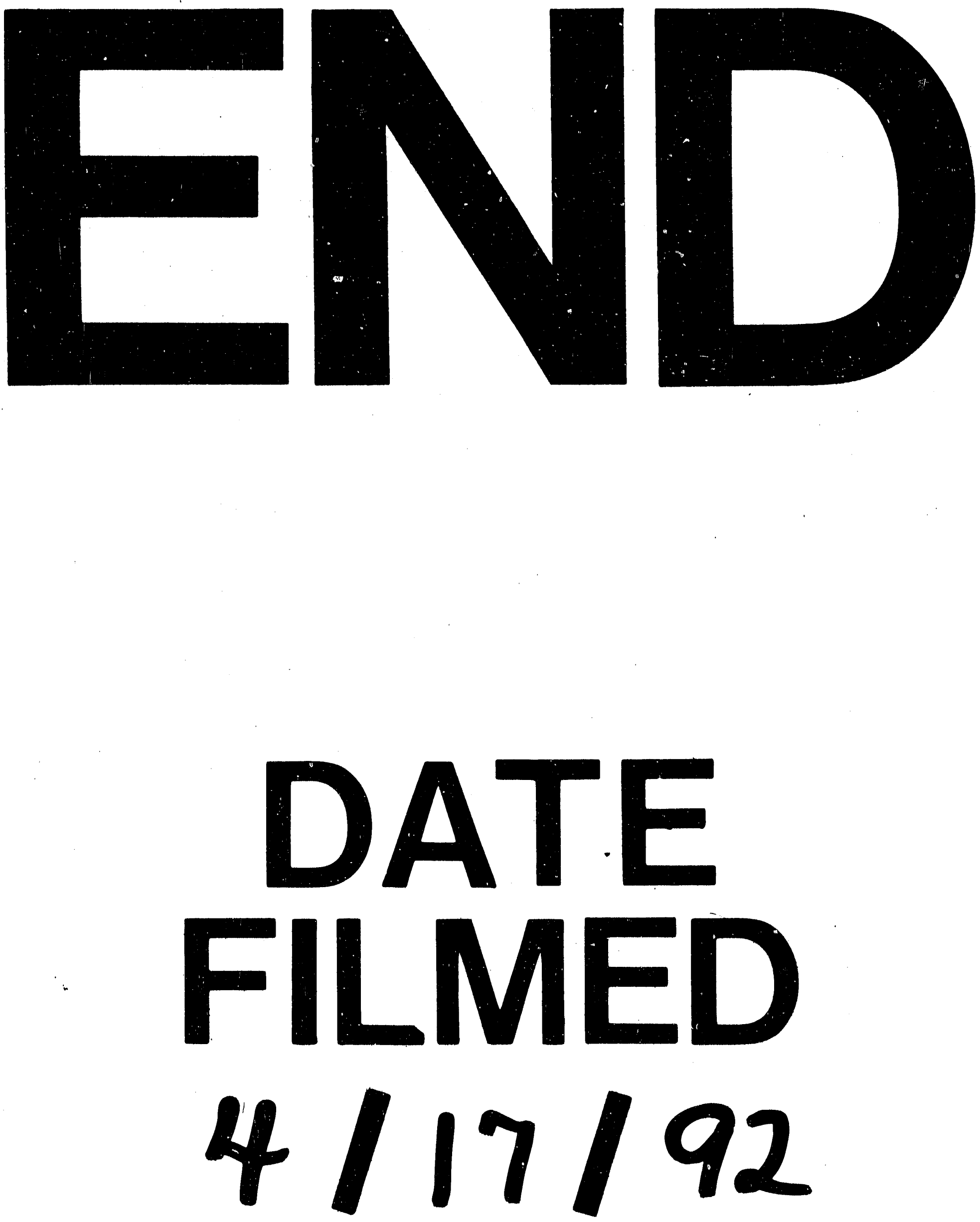
